\title{
Marine Cytotoxic Macrolides Haterumalides and Biselides, and Related Natural Products
}

\author{
Hideo Kigoshi, Ichiro Hayakawa
}

Department of Chemistry, Graduate School of Pure and Applied Sciences, and Center for Tsukuba Advanced Research Alliance, University of Tsukuba, Tennodai, Tsukuba 305-8571, Japan

\begin{abstract}
Marine animals and plants are rich sources of bioactive natural products. Haterumalides and biselides, isolated from Okinawan marine animals, are 14-membered macrolides with strong cytotoxicity against human cancer cell lines. This review highlights the isolation, structures, bioactivities, and total synthesis of haterumalides, biselides, and related natural products.
\end{abstract}

Keywords: marine cytotoxic macrolide; haterumalides; biselides; human cancer cell lines

\section{Introduction}

Marine animals and plants are rich sources of bioactive natural products. ${ }^{1}$ The search for antitumor substances from marine organisms has been conducted worldwide, and many cytotoxic and/or antitumor marine natural products have been isolated, some of which are promising for anticancer chemotherapy. Some examples are halichondrin B, discodermolide, and cryptophycin from sponges; didemnin B, aplidine, and ecteinascidin 743 from ascidians; bryostatin 1 from a bryozoan; and dolastatin 10 and kahalalide $\mathrm{F}$ from sea hare. Because many of these compounds were isolated from tropical or subtropical seas, marine organisms in tropical and subtropical zones have attracted the interest of natural product chemists and pharmaceutical scientists.

\section{Isolation and Biological Activities of Haterumalides, Biselides, and Related Compounds}

In 1999, the first haterumalide family was isolated from an Okinawan ascidian by Ueda and $\mathrm{Hu}^{2}$ and from an Okinawan sponge by Uemura and coworkers (Figure 1). ${ }^{3}$ Ueda and Hu isolated haterumalide B (6) from the Okinawan ascidian Lissoclinum sp. and determined the structure with partial stereochemistry spectroscopically. Haterumalide B (6) completely inhibited the first cleavage of fertilized sea urchin eggs at a concentration of $0.01 \mu \mathrm{g} / \mathrm{mL}$. At the same time, Uemura and coworkers isolated haterumalides NA (1), NB (2), NC (3), ND (4), and NE (5) from the Okinawan sponge Ircinia sp. Although these compounds were isolated as very minute components of the animal, they helped elucidate the absolute stereostructure of haterumalide NA (1) by detailed spectroscopic analysis and the modified Mosher method, ${ }^{4}$ as shown in structural formula $\mathbf{1}$. Later, they revised the relative stereochemistry and determined the absolute stereochemistry of haterumalide NA in an organic synthetic manner. ${ }^{5}$ Haterumalide NA (1) exhibited cytotoxicity against P388 cells, with an $\mathrm{IC}_{50}$ of $0.32 \mu \mathrm{g} / \mathrm{mL}$, and moderate acute toxicity against mice, with an $\mathrm{LD}_{99}$ of $0.24 \mathrm{~g} / \mathrm{kg}$.

That same year, an anti-oomycete compound, oocydin A (12), was isolated from South American epiphyte Serratia marcescens by Strobel and coworkers. ${ }^{6}$ The gross structure with partial stereochemistry was determined by spectroscopic analysis.

Thaning and coworkers screened 300 bacterial isolates for the ability to suppress apothecial formation of Sclerotinia sclerotiorum and isolated haterumalide NA/oocydin A from the soil bacterium Serratia plymuthica as an active compound. ${ }^{7}$

Levenfors and coworkers isolated haterumalide X from the soil bacterium Serratia plymuthia along with haterumalides NA (1), B (6), and NE (5). ${ }^{8}$ Haterumalide $X$ was found to be the $Z$ isomer of the C16 double bond in haterumalide NA (1). They could not collect antifungal data on haterumalide X because this compound is easily converted into haterumalide NA (1).

Later, researchers at Fujisawa Pharmaceutical Company isolated an antimicrobial component, 
FR177391 (13), from the soil bacterium Serratia liquefaciens. The structure was determined by X-ray crystallographic analysis of the propylamide derivative. ${ }^{9}$ This compound is the enantiomer of haterumalide NA (1). They reported on a detailed study of its anti-hyperlipidemic activity ${ }^{10}$ and the microbial conversion into 20-hydroxy FR177391 (14). ${ }^{11}$ In addition, they identified its molecular target as protein phosphatase $2 \mathrm{~A}(\mathrm{PP} 2 \mathrm{~A}) .^{12}$

It is notable that haterumalides NA (1) and B (6), which are marine natural products, are levorotatory, while oocydin A (12) and FR177391 (13) from an epiphyte of an aquatic plant and a soil bacterium are dextrorotatory.

In 2004, Kigoshi and coworkers isolated biselides A (7) and B (8), oxygenated analogs of haterumalides, from the Okinawan ascidian Didemnidae sp. and determined their structures by detailed spectroscopic analysis (Figure 1$).^{13}$ The next year, they reported the isolation of three more analogs, biselides C (9)-E (11) and compared the cytotoxicity of biselides A (7) and C (9) with that of haterumalide NA methyl ester (15). ${ }^{14}$ The order of the cytotoxicity is haterumalide NA methyl ester (15) > biselide A (7) > biselide C (9). Among the tested cell lines, biselide A (7) showed the strongest cytotoxicity against human colon cancer DLD-1 $(0.513 \mu \mathrm{M})$. Interestingly, haterumalide NA (1) showed strong toxicity against brine shrimp, with an $\mathrm{LD}_{50}$ of $0.6 \mu \mathrm{g} / \mathrm{mL}$, while biselides A (7) and C (9) showed no toxicity against brine shrimp, even at $50 \mu \mathrm{g} / \mathrm{mL}$. It is worth noting that 20-hydroxy FR177331 (14), the microbial oxidation compound of FR177331 (13), has the same planar structure as biselide $\mathrm{C}$ (9).

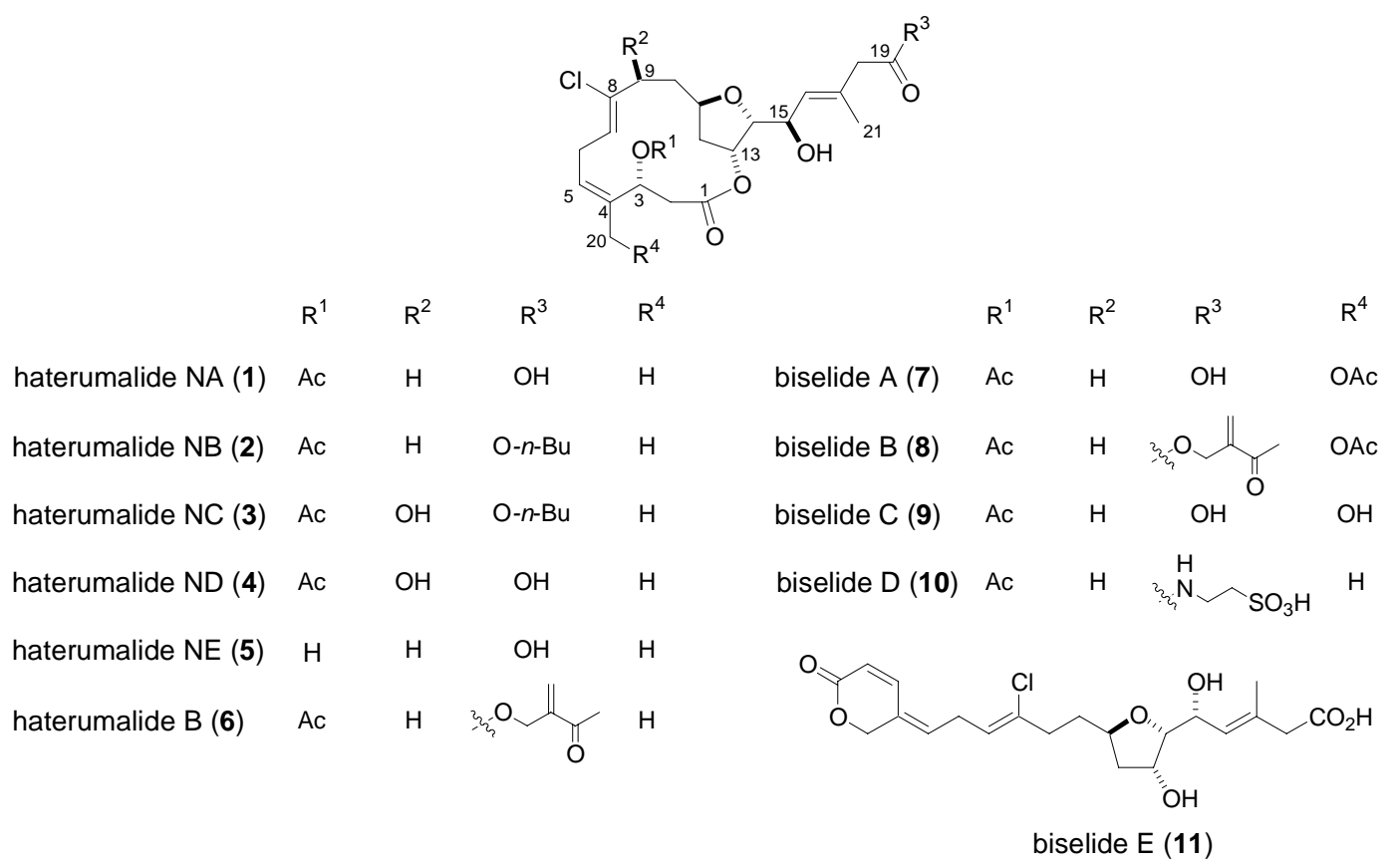

Figure 1. Structures of haterumalides and biselides
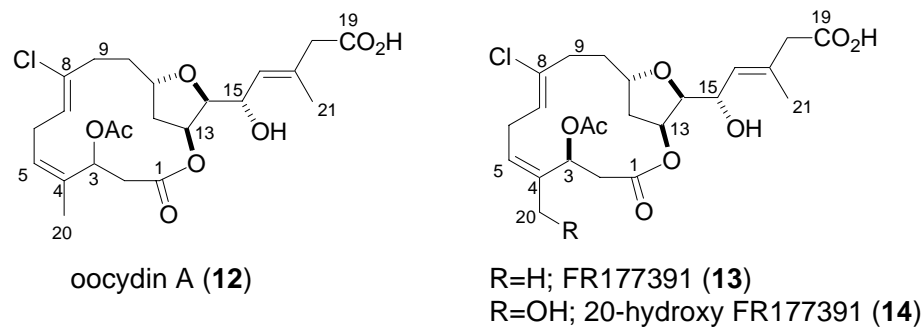

Figure 2. Structures of oocydin A, FR177391, and 20-hydroxy FR177391

\section{Synthetic Studies of Haterumalides}




\section{Studies in Kigoshi's Laboratory}

The first report concerning haterumalides from the Kigoshi laboratory described an enantioselective synthesis of ent-haterumalide NA methyl ester (15). ${ }^{5}$ This synthesis revised the stereochemistry of haterumalide NA and determined its absolute stereochemistry.

Their synthetic route to ent-haterumalide NA methyl ester (15) involved a key macrocyclization at C2-C3 using an intramolecular Reformatsky-type reaction (Scheme 1). They also developed a coupling between aldehyde $\mathbf{1 6}$ and iodoolefin $\mathbf{1 7}$ at C15-C16 using a Nozaki-Hiyama-Kishi coupling. ${ }^{15}$

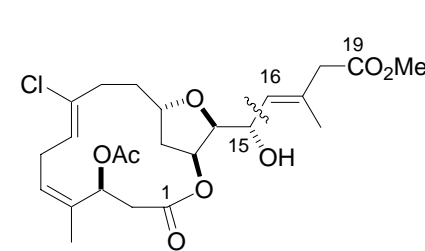

ent-haterumalide NA methyl ester (15)

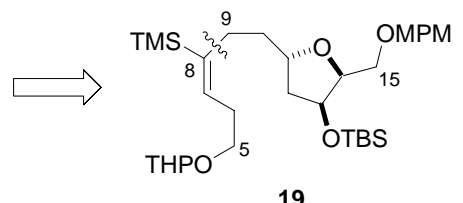

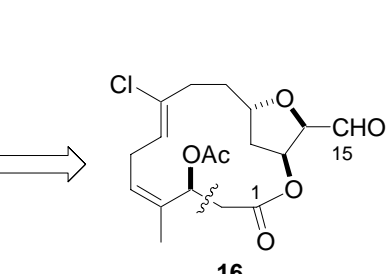

16
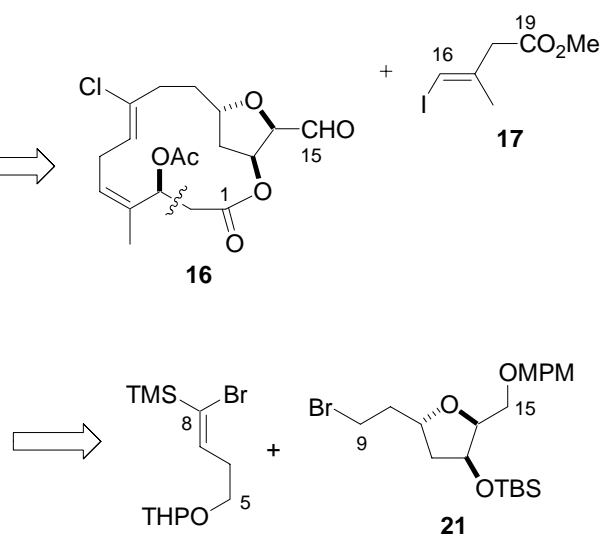

20

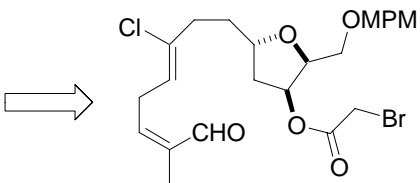

18

Scheme 1. Strategy for the synthesis of haterumalide NA methyl ester developed by Kigoshi et al. MPM, pmethoxyphenylmethyl; FAMSO, formaldehyde dimethyldithioacetal $S$-oxide.

The starting point for this work was the construction of the tetrahydrofuran unit (Scheme 2). Mono-MPM ether 22 was synthesized from commercially available (+)-2,3-O-isopropylidene-L-threitol. After transformation into the corresponding iodide, C1 homologation was achieved by using the FAMSO carbanion to afford sulfoxide 23. Sequential acidic methanolysis and hydrolysis afforded a hemiacetal 24. The Wittig reaction of $\mathbf{2 4}$ and cyclization provided a 5.3:1 diastereomeric mixture of tetrahydrofurans, which were separated after silylation to afford the desired trans-tetrahydrofuran $\mathbf{2 6}$ and cis-isomer. The latter was isomerized into a 1:1 mixture under basic conditions. The desired trans-tetrahydrofuran $\mathbf{2 6}$ was quantitatively converted into bromide 21 in three steps.

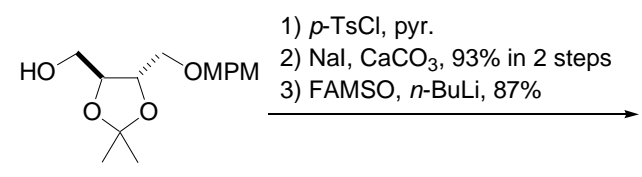

22

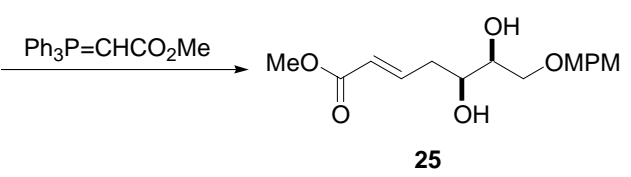

25<smiles>COCC1O[C@@H](CCBr)CC1[O+]</smiles>

21

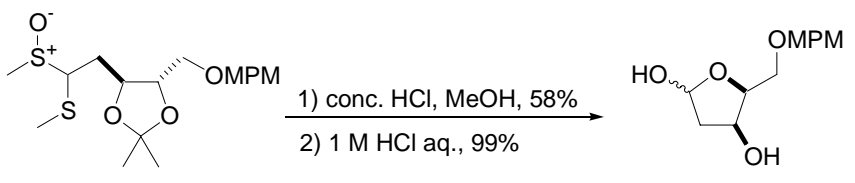

23

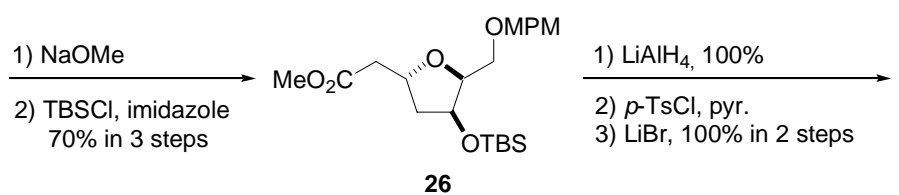

26

Scheme 2. Synthesis of trans-2,5-dialkyl tetrahydrofuran unit according to Kigoshi et al. TMS, trimethylsilyl; THP, tetrahydropyranyl; MPM, p-methoxyphenylmethyl; TBS, tert-butyldimethylsilyl; HMPA, hexamethylphosphoramide; NCS, N-chlorosuccinimide; DMF, $\mathrm{N}$, $\mathrm{N}$-dimethylformamide; KHMDS, potassium hexamethyldisilazane; DIBAL, diisobutylaluminium 
hydride; MMTr, p-methoxyphenyldiphenylmethyl.

The coupling reaction between the tetrahydrofuran unit $\mathbf{2 1}$ and a carbanion generated from Z-alkenylsilane 20 gave alkenylsilane 19 (Scheme 3). The stereoselective construction of a chloroolefin unit from alkenylsilane 19 was achieved by a modification of Tamao's procedure ${ }^{16}$ for conversion of an alkenylsilane to a bromoolefin. Kigoshi et al. found that the addition of a catalytic amount of water was important for the reaction to be reproducible. Acidic hydrolysis of $\mathbf{2 7}$ and subsequent Dess-Martin oxidation afforded a labile aldehyde, which was converted into the Z-conjugated ester $\mathbf{2 8}$ by using the Still-modified Horner-Wadsworth-Emmons reaction. ${ }^{17}$ The DIBAL reduction of $\mathbf{2 8}$ gave an allylic alcohol, the hydroxy group of which was protected as an MMTr ether to afford compound 29 quantitatively. The silyl group in 29 was removed, and the resulting alcohol was converted into a bromo ester. The MMTr group was removed, and the resulting allylic alcohol was oxidized to afford the conjugated aldehyde 18, a precursor of the intramolecular Reformatsky-type reaction.
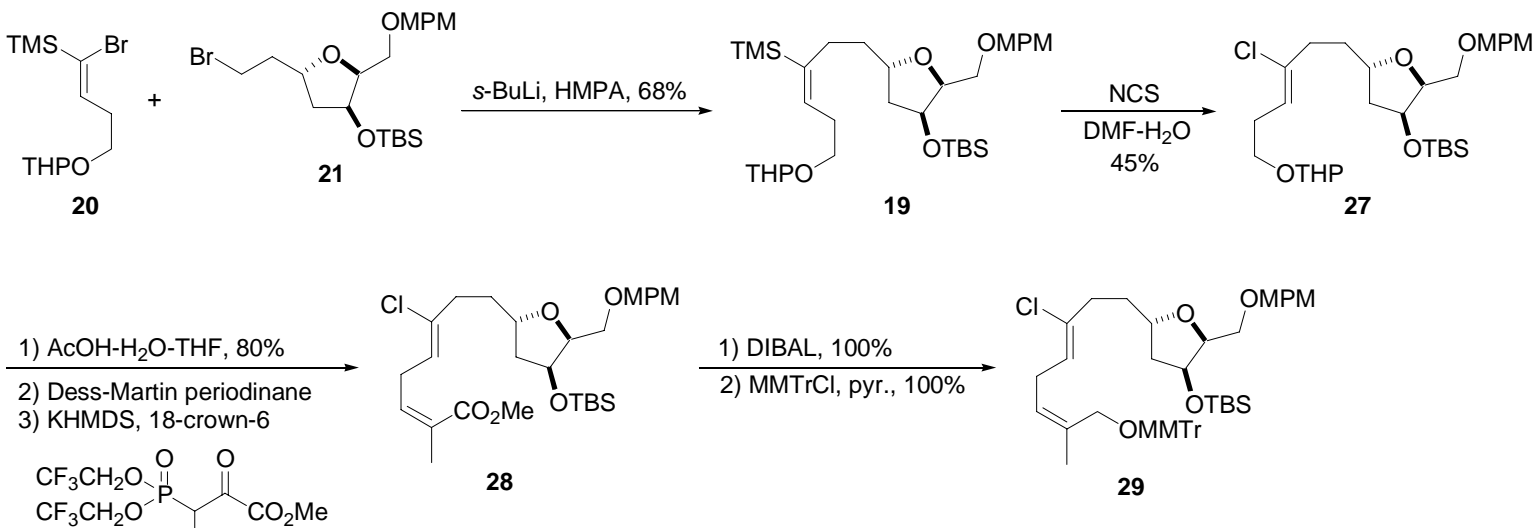

$75 \%$ in 2 steps
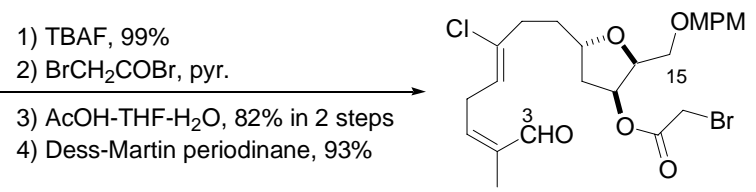

18

Scheme 3. Synthesis of the C3-C15 segment of haterumalide NA methyl ester according to Kigoshi et al. TMS, trimethylsilyl; THP, tetrahydropyranyl; MPM, p-methoxyphenylmethyl; TBS, tert-butyldimethylsilyl; HMPA, hexamethylphosphoramide; NCS, $N$-chlorosuccinimide; DMF, $N, N$-dimethylformamide; KHMDS, potassium hexamethyldisilazane; DIBAL, diisobutylaluminium hydride; MMTr, p-methoxyphenyldiphenylmethyl.

Cyclization under Honda's conditions, ${ }^{18} \mathrm{Et}_{2} \mathrm{Zn}-\mathrm{RhCl}\left(\mathrm{PPh}_{3}\right)_{3}$, followed by the addition of $\mathrm{Ac}_{2} \mathrm{O}$ to trap the reactive products afforded the desired cyclized product in $9 \%$ yield along with the $(3 R, 4 Z)$ and (4E) isomers (Scheme 4). The MPM group was removed to give alcohol 30. The Nozaki-Hiyama-Kishi coupling reaction of iodide $\mathbf{1 7}$ and aldehyde $\mathbf{1 6}$ derived from $\mathbf{3 0}$ afforded the coupling product $\mathbf{1 5}(57 \%, S: R=11: 1)$. The major isomer, $(15 S)-\mathbf{1 5}$, was found to be the enantiomer of the naturally occurring haterumalide NA methyl ester 15 upon comparison of their spectral data. These results determined the total absolute stereochemistry, which revised the proposed structure. 


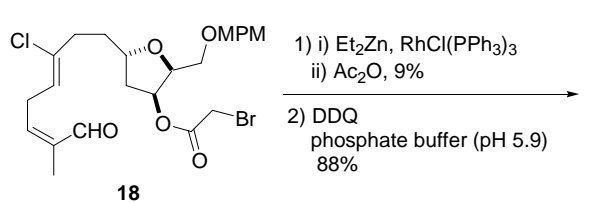

18

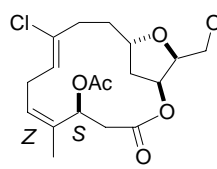

30

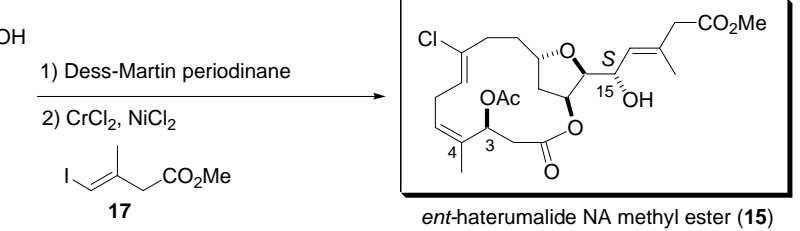

$57 \%, 15 S: 15 R=11: 1$, in 2 steps

Scheme 4. Synthesis of ent-haterumalide NA methyl ester according to Kigoshi et al. DDQ, 2,3-dichloro-5,6-dicyano-1,4-benzoquinone; Ac, acetyl.

\section{Studies in Snider's Laboratory}

Snider et al. reported the total synthesis of ent-haterumalide NA methyl ester (15). ${ }^{19}$ Their strategy involved a key fragment coupling at C5-C6 using a Stille coupling (Scheme 5). ${ }^{20}$ They also accomplished macrocyclization of a seco acid by Yamaguchi conditions. ${ }^{21}$

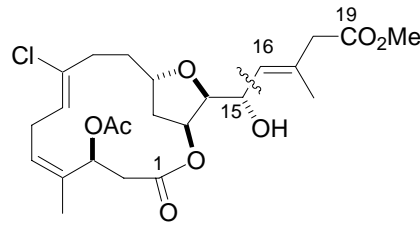

ent-haterumalide NA methyl ester (15)

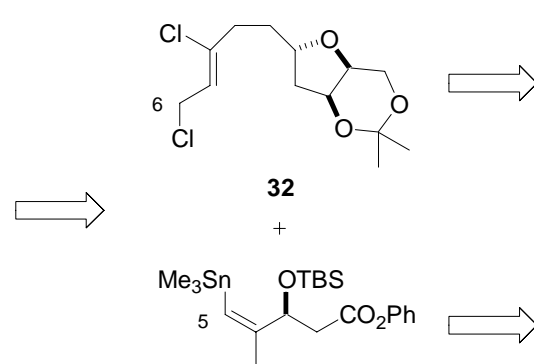

33

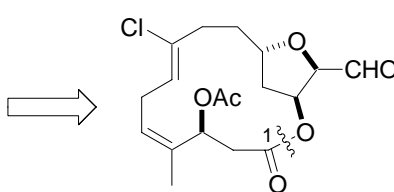

16<smiles>C=C[C@H](O)CC1=CC(=O)OC(C)(C)O1</smiles>

34<smiles>C#CCO</smiles>

35

Scheme 5. Strategy for the synthesis of haterumalide NA methyl ester developed by Snider et al.

The synthetic route reported by Snider begins with the preparation of optically active vinylstannane 33 (Scheme 5). The Z-methyl-substituted alkene unit $\mathbf{3 6}$ was prepared by the Cu-catalyzed methylmagnesation of propargyl alcohol $35^{22}$ followed by iodinolysis. Iodoalkene $\mathbf{3 6}$ was oxidized with $\mathrm{MnO}_{2}$ to afford an iodoaldehyde. The asymmetric aldol reaction of the iodoaldehyde with the ketene silyl acetal $\mathbf{3 7}$ by using Kiyooka's oxaborolidinone $\mathbf{3 8}$ provided the $\beta$-hydroxy phenyl ester $39 .^{23}$ The allylic hydroxyl group of $\mathbf{3 9}$ was protected as a TBS ether, and the resulting vinyl iodide was converted into the vinylstannane 33.

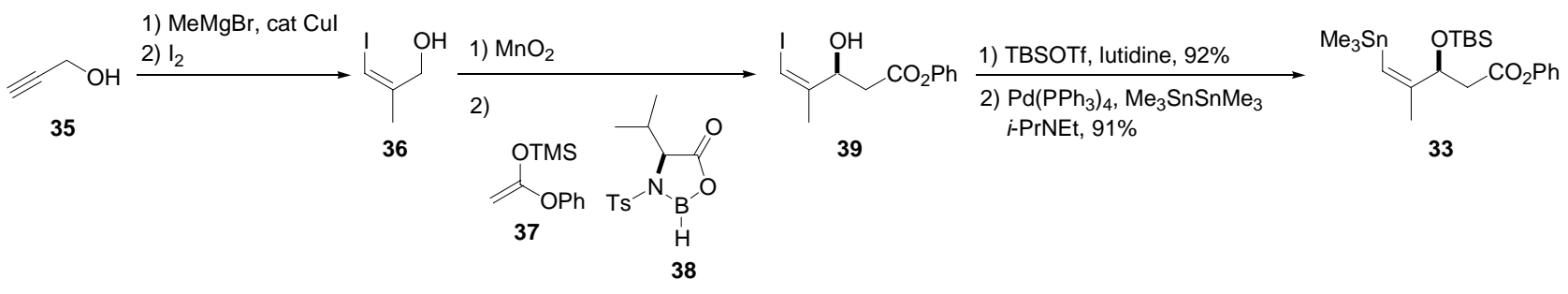

$65 \%$ in 2 steps, $80 \%$ ee

Scheme 6. Synthesis of vinylstannane 33 according to Snider et al. TMS, trimethylsilyl; TBSOTf, trifluoromethanesulfonic acid tert-butyldimethylsilyl ester; i-Pr $2 \mathrm{NEt}, \mathrm{N}, \mathrm{N}$-diisopropylethylamine; TBS, tert-butyldimethylsilyl.

In contrast, an optically active alcohol 34 was prepared via an asymmetric aldol reaction between the 
O-TMS dienolate $\mathbf{4 0}$ and acrolein (41) by using Carreira's Ti(IV) catalyst $\mathbf{4 2},{ }^{24}$ or kinetic resolution of the racemic alcohol 43 via Sharpless asymmetric epoxidation (Scheme 7). ${ }^{25}$

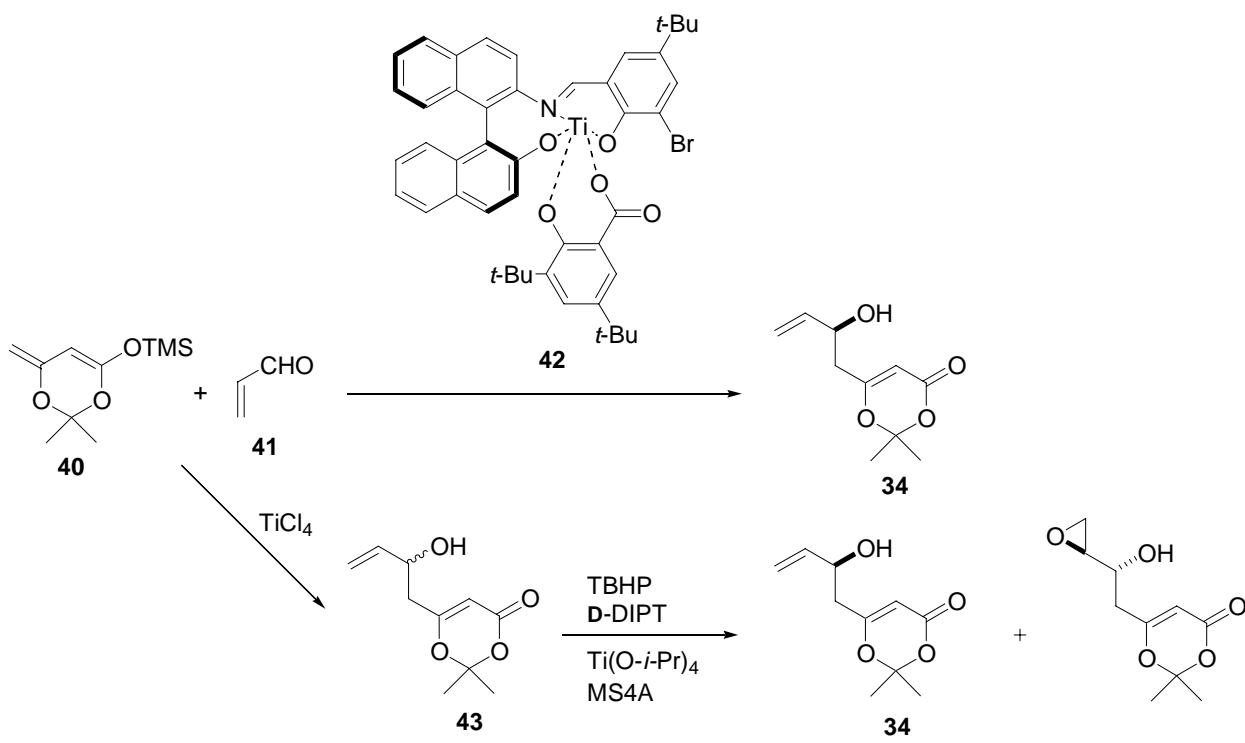

Scheme 7. Synthesis of optically active diol 34 according to Snider et al. TMS, trimethylsilyl; TBHP, tertbutylhydroperoxide; DIPT, diisopropyl tartrate; MS4A, molecular sieves 4A.

Alcohol 34 was converted to a keto ester, the stereoselective reduction of which with $\mathrm{Et}_{2} \mathrm{BOMe}$ and $\mathrm{NaBH}_{4}$ afforded syn diol $\mathbf{4 4}$ (Scheme 8). Diol $\mathbf{4 4}$ was protected as an acetonide, and the ester group was transformed into an alkyl iodide group in a sequence of reactions to afford iodide $\mathbf{4 5}$. The coupling reaction between iodide $\mathbf{4 5}$ and acetylide $\mathbf{4 6}$ generated from the tert-butyldimethylsilyl propargyl ether gave a coupling compound (92\%). The acetonide group was removed to give diol 47 by using $\mathrm{BF}_{3} \cdot \mathrm{OEt}_{2}$ and propanedithiol. The stereoselective intramolecular iodoetherification of 47 afforded iodomethyltetrahydrofuran 48 (81\%) in $>90 \%$ de. After acetylation of the secondary hydroxyl group, the iodomethyl group was transformed into the desired hydroxymethyl group by using $m$-CPBA, and the acetyl group was cleaved to afford diol 49. Diol 49 was protected as an acetonide, and the TBS group was removed to give the propargylic alcohol. A regioselective hydroalumination of the propargylic alcohol by using Red-Al ${ }^{\circledR}$ and subsequent treatment with NCS furnished the desired Z-chloro allylic alcohol. Reaction of the allylic alcohol with $\mathrm{MsCl}_{2} \mathrm{Et}_{3} \mathrm{~N}$, and then $\mathrm{LiCl}$ afforded dichloride 32. 

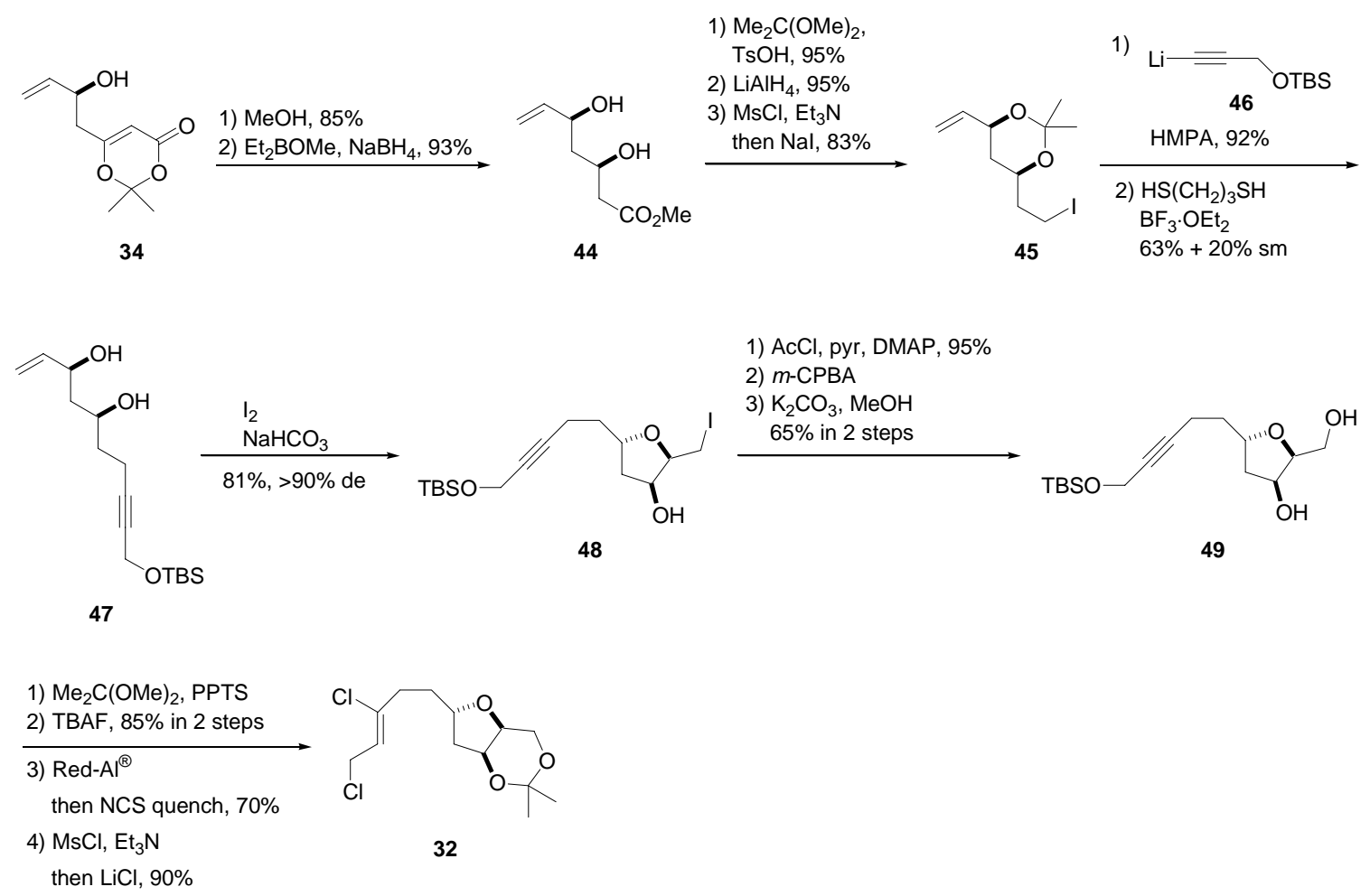

Scheme 8. Synthesis of Stille coupling precursor 32 according to Snider et al. TBS, tert-butyldimethylsilyl; HMPA, hexamethylphosphoramide; $m$-CPBA, $m$-chloroperbenzoic acid; PPTS, pyridinium $p$-toluenesulfonate; TBAF, tetrabutylammonium fluoride; Red-Al ${ }^{\circledR}$, sodium bis(2-methoxyethoxy)-aluminium hydride; NCS, $N$-chlorosuccinimide.

A Stille coupling reaction ${ }^{20}$ between dichloride 32 and vinylstannane 33 with $\mathrm{Pd}_{2} \mathrm{dba}_{3}$ and $\mathrm{AsPh}_{3}$ afforded 50 (65\%) and the corresponding (E)-isomer (Scheme 9). The acetonide group was removed by using CSA to give a diol, and selective tritylation of the primary hydroxy group in the diol and hydrolysis of the phenyl ester afforded the seco acid 31. The macrolactonization of $\mathbf{3 1}$ was accomplished by the Yamaguchi method ${ }^{21}$ to give the desired lactone $\mathbf{5 1}$ along with the dimer and the trimer. The TBS group in $\mathbf{5 1}$ was removed, and the resulting alcohol was converted into an acetate. The trityl group was removed to give the primary alcohol 30, which is the key intermediate in Kigoshi's synthesis. ${ }^{5}$ From this point on, the earlier synthesis was followed. Oxidation with Dess-Martin periodinane and Nozaki-Hiyama-Kishi coupling ${ }^{15}$ with iodide 17 afforded 30-40\% of haterumalide NA methyl ester (15) after HPLC purification. 
<smiles>CC1(C)OCC2O[C@@H](CCC(Cl)=CCCl)CC2O1</smiles>

32

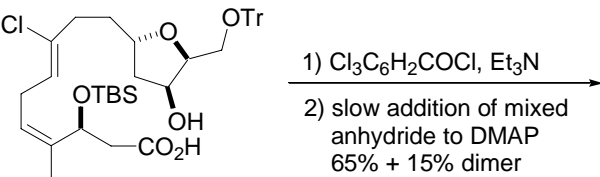

31<smiles>CC(=CC(C)C)C(CC(=O)Oc1ccccc1)Oc1ccccc1</smiles>

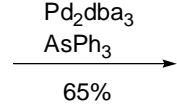<smiles>C/C(=C/CC(Cl)=CCC[C@H]1OC2COC(C)(C)OC2[C@@H]1[B]CC(=O)c1ccccc1)C(=O)O</smiles>

50

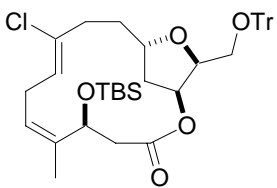

51

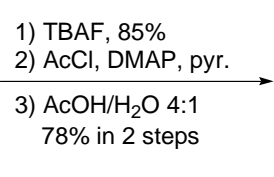

$\mathrm{AcOH} / \mathrm{H}_{2} \mathrm{O} 4: 1$
$78 \%$ in 2 steps

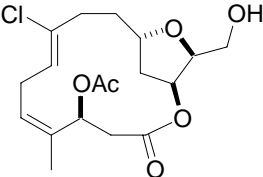

Kigoshi's intermediate $\mathbf{3 0}$

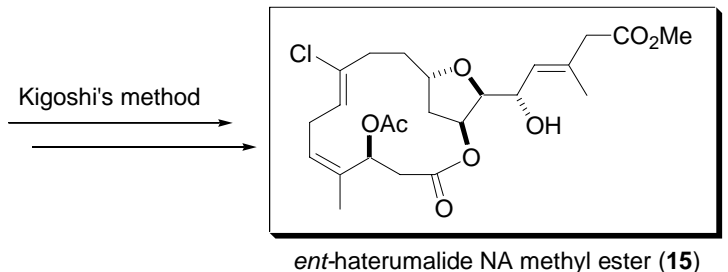

Scheme 9. Synthesis of ent-haterumalide NA methyl ester according to Snider et al. CSA, camphorsulfonic acid; Tr, triphenylmethyl; DMAP, 4-(dimethylamino)pyridine; TBAF, tetrabutylammonium fluoride; Ac, acetyl.

\section{Studies in Hoye's Laboratory}

Hoye et al. first achieved the total synthesis of haterumalide NA (1) itself. ${ }^{26}$ Their synthetic route to haterumalide NA involved a key intramolecular cyclization at C6-C7, based on the Kaneda reaction ${ }^{27}$ (Scheme 10).

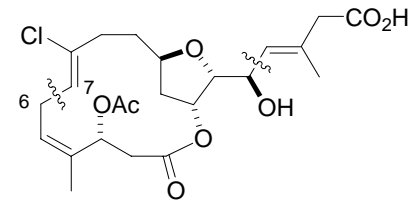

haterumalide NA (1)

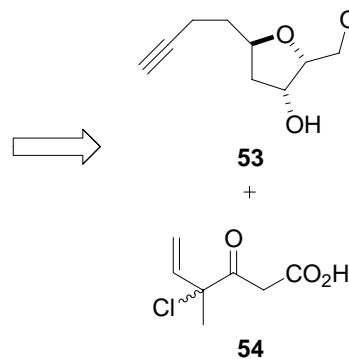

54

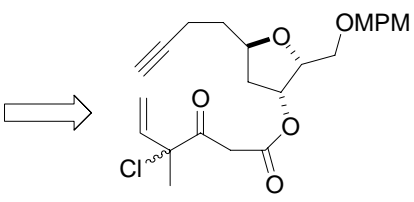

52

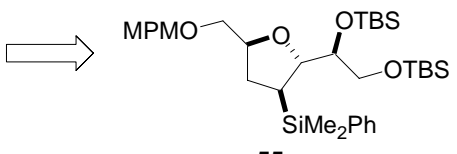

Scheme 10. Strategy for the synthesis of haterumalide NA developed by Hoye et al.

Kaneda et al. reported $\mathrm{PdX}_{2}$-catalyzed coupling reactions of terminal alkynes with allylic chlorides and bromides to produce crossed 1:1 adducts (Scheme 11). The catalytic cycle for the Kaneda reaction has three steps: 1) cis-addition of the $\mathrm{PdX}_{2}$-catalyst into alkyne; 2) allylic halide inserts into a Pd-vinyl bond; and 3) $\beta$-elimination to give a crossed 1:1 adduct. 


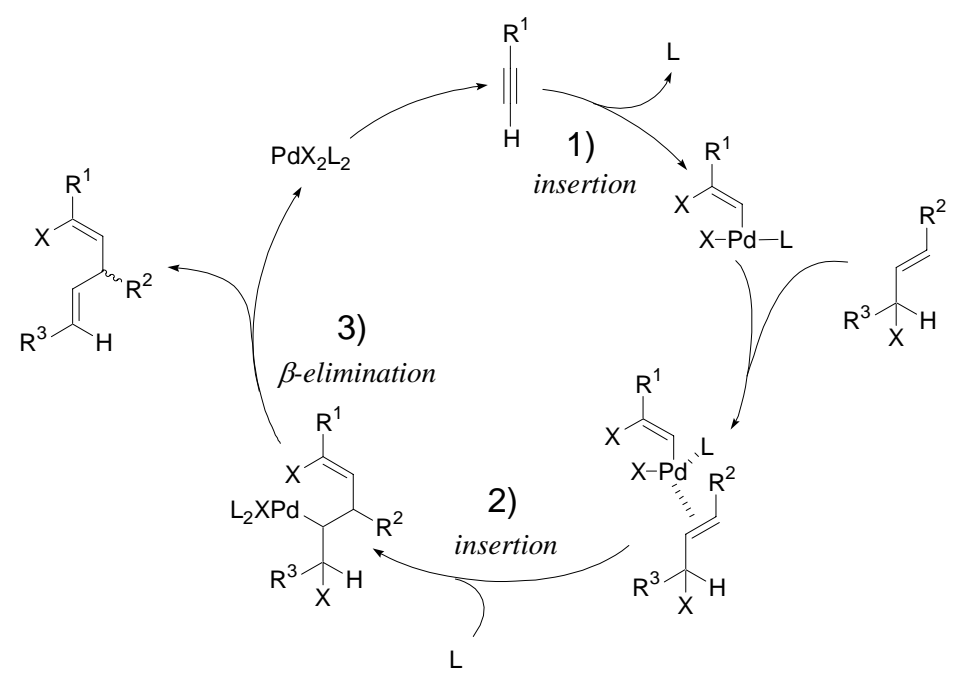

Scheme 11. Mechanism of the Kaneda reaction

The synthetic route reported by Hoye begins with the preparation of a 3-hydroxy tetrahydrofuran derivative by Roush's method (Scheme 12). ${ }^{28}$ The [3+2] annulation of the allylsilane 57 with $\alpha$-(p-methoxybenzyloxy)acetoaldehyde $\mathbf{5 6}$ was performed using $\mathrm{SnCl}_{4}$ as the Lewis acid catalyst to provide the 2,5-trans-substituted tetrahydrofuran $\mathbf{5 8}$. The TBS groups in $\mathbf{5 8}$ were removed, and the resulting diol was converted into an acetonide. The phenyldimethylsilyl group was oxidized by Tamao-Woerpel oxidation $^{29}$ to provide a secondary alcohol. After inversion of the resulting secondary alcohol under Mitsunobu conditions, ${ }^{30}$ the MPM ether group was converted into a propargyl group to give compound 53. Esterification between $\mathbf{5 3}$ and allylic chloride $\mathbf{5 4}$ afforded ene-yne 52. This ene-yne compound 52 was a precursor of the Kaneda reaction.
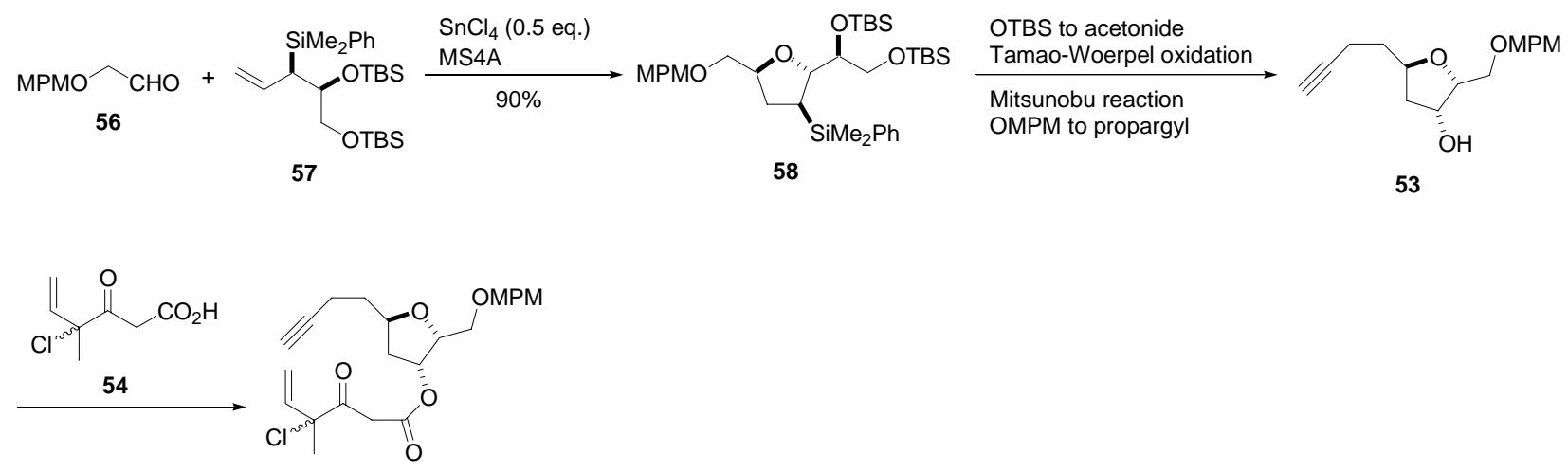

52

Scheme 12. Synthesis of Kaneda reaction precursor 52 according to Hoye et al. MS4A, molecular sieves 4A; MPM, p-methoxyphenylmethyl; TBS, tert-butyldimethylsilyl.

The intramolecular macrocyclization of $\mathbf{5 2}$ was accomplished by the Kaneda reaction to give the desired 14-membered macrolactone 59 (Scheme 13). This compound $\mathbf{5 9}$ has the desired stereostructure at the $Z-\Delta^{7,8}$-alkene, but the $\Delta^{4,5}$-alkene was produced as a separable mixture of the isomers. Reduction of the C-3 ketone in the Z-isomer of $\mathbf{5 9}$ under Luche conditions gave an alcohol as the desired single diastereomer. Acetylation of the resulting hydroxyl group and removal of the MPM group gave alcohol ent-30, which is the intermediate in Kigoshi's route. ${ }^{5}$

To convert ent-30 into haterumalide NA, they followed Kigoshi's procedure ${ }^{5}$ with a modification. Oxidation with Dess-Martin periodinane and Nozaki-Hiyama-Kishi coupling ${ }^{15}$ with the MPM ester $\mathbf{6 0}$ afforded haterumalide NA MPM ester $\mathbf{6 1}$. The MPM ester in $\mathbf{6 1}$ was cleaved with TFA and $\mathrm{Et}_{3} \mathrm{SiH}$ to afford haterumalide NA (1). 

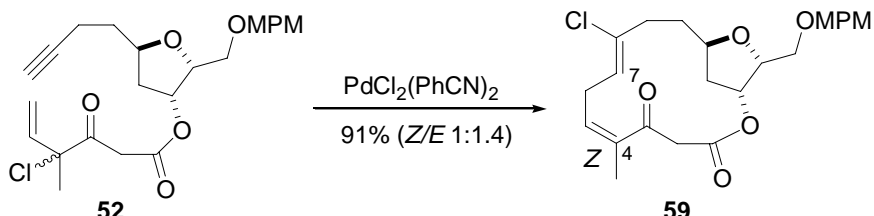

59
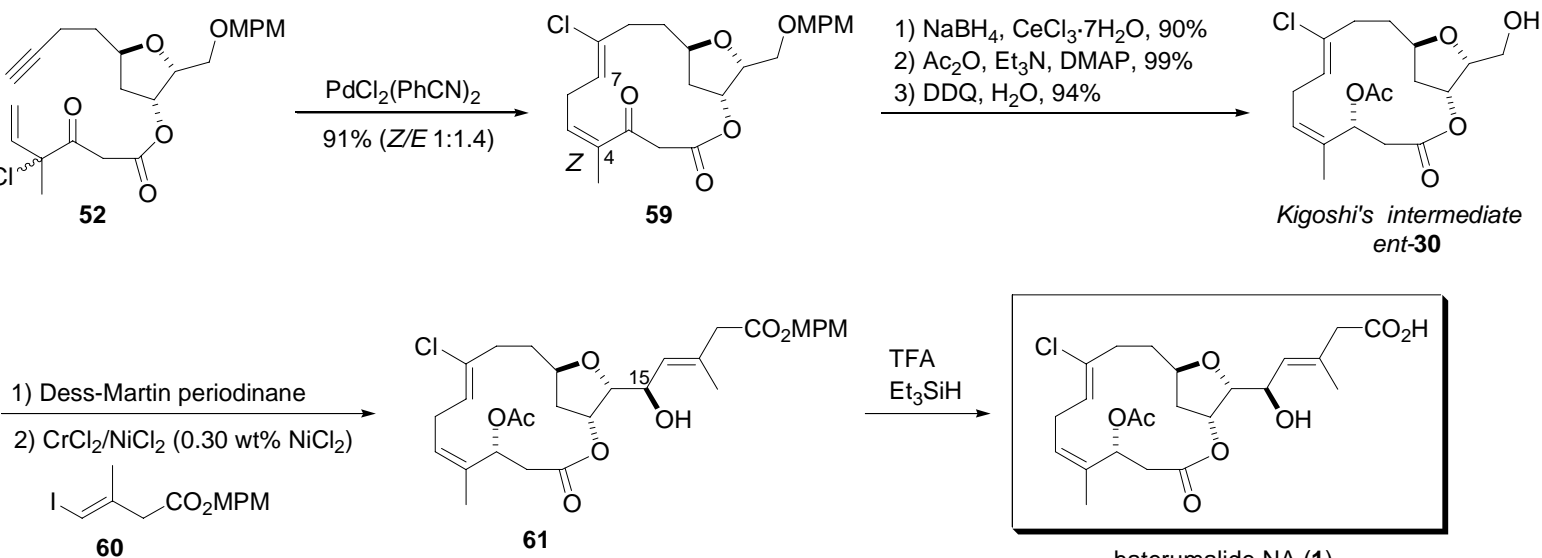

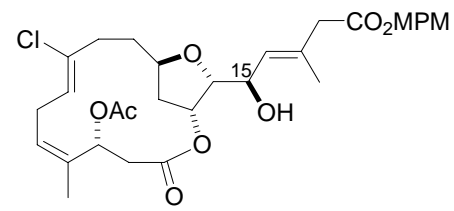

61

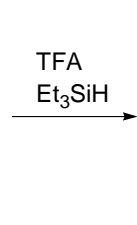

$\mathrm{t}_{3} \mathrm{SiH}$

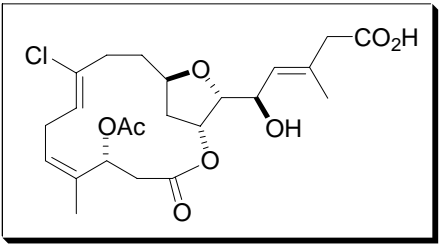

haterumalide NA (1)

50\%, 15R:15S = 10:1, in 2 steps

Scheme 13. Total synthesis of haterumalide NA according to Hoye et al. MPM, p-methoxyphenylmethyl; $\quad$ DMAP, 4-(dimethylamino)pyridine; 2,3-dichloro-5,6-dicyano-1,4-benzoquinone; Ac, acetyl; TFA, trifluoroacetic acid.

\section{Conclusion}

Although marine natural products are regarded as promising sources of drug discovery, the limited supply of compounds prevents their development as medicines. Haterumalides and biselides are new types of cytotoxic compounds in minute quantities. The studies discussed in this review develop efficient synthetic routes to enable further biological and preclinical evaluations of these compounds. From a synthetic perspective, it is interesting to note that three syntheses employed different strategies to construct a 14-membered macrolactone ring.

\section{We thank Professor Daisuke Uemura (Nagoya University) for valuable discussions.}

\section{REFERENCES}

1. Fusetani, N. Drugs from the Sea, Karger: Tokyo, 2000.

2. $\quad$ Ueda, K.; Hu, Y. Tetrahedron Lett 1999, 40, 6305-6308.

3. Takada, N.; Sato, H.; Suenaga, K.; Arimoto, H.; Yamada, K.; Ueda, K.; Uemura, D. Tetrahedron Lett 1999, 40, 6309-6312.

4. Ohtani, I.; Kusumi, T.; Kashman, Y.; Kakisawa, H. J Am Chem Soc 1991, 113, 4092-4096.

5. Kigoshi, H.; Kita, M.; Ogawa, S.; Itoh, M.; Uemura, D. Org Lett 2003, 5, 957-960.

6. Strobel, G.; Li, J.-Y.; Sugawara, F.; Koshino, H.; Harper, J.; Hess, W. M. Microbiology 1999, 145, 3557-3564.

7. Thaning, C.; Welch, C. J.; Borowiez, J. J.; Hedman, R.; Gerhardson, B. Soil Biol Biochemistry 2001, 33, 1817-1826.

8. Levenfors, J. J.; Hedman, R.; Thaning, C.; Gerhardson, B.; Welch, C. J Soil Biol Biochemistry 2004, 36, 677-685.

9. Sato, B.; Nakajima, H.; Fujita, T.; Takase, S.; Yoshimura, S.; Kinoshita, T.; Terano, H. J Antibiot 2005, 58, 634-639.

10. Inai, M.; Kawamura, I.; Tsujimoto, S.; Yasuno, T.; Lacey, E.; Hirosumi, J.; Takakura, S.; Nishigaki, F.; Naoe, Y.; Manda, T.; Mutoh, S. J Antibiot 2005, 58, 640-647.

11. Kobayashi, M.; Sato, K.; Yoshimura, S.; Yamaoka, M.; Takase, S.; Ohkuba, M.; Fujii, T.; Nakajima, H. J Antibiot 2005, 58, 648-653.

12. Yamaoka, M.; Sato, K.; Kobayashi, M.; Nishio, N.; Ohkubo, M.; Fujii, T.; Nakajima, H. J Antibiot 2005, 58, 654-662.

13. Teruya, T.; Shimogawa, H.; Suenaga K.; Kigoshi, H. Chem Lett 2004, 33, 1184-1185.

14. Teruya, T.; Suenaga K.; Maruyama, S.; Kurotaki, M.; Kigoshi, H. Tetrahedron 2005, 61, 6561-6567. 
15a. Takai, K.; Kimura, K.; Kuroda, T.; Hiyama, T.; Nozaki, H. Tetrahedron Lett 1983, 24, 5281-5284.

15b. Jin, H.; Uenishi, J.; Christ, W. J.; Kishi, Y. J Am Chem Soc 1986, 108, 5644-5646.

16. Tamao, K.; Akita, M.; Maeda, K.; Kumada, M. J Org Chem 1987, 52, 1100-1106.

17. Still, W. C.; Gennari, C. Tetrahedron Lett 1983, 24, 4405-4408.

18. Kanai, K.; Wakabayashi, H.; Honda, T. Org Lett 2000, 2, 2549-2551.

19. Gu, Y.; Snider, B. B. Org Lett 2003, 5, 4385-4388.

20. Sheffy, F. K.; Goodschax, J. P.; Stille, J. K. J Am Chem Soc 1984, 106, 4833-4840.

21. Inanaga, J.; Hirata, K.; Saeki, H.; Katsuki, T.; Yamaguchi, M. Bull Chem Soc Jpn. 1979, 52, 1989-1993.

22. Liu, F.; Negishi, E.-i. J Org Chem 1997, 62, 8591-8594.

23. Kiyooka, S.-i.; Hena, M. A. J Org Chem 1999, 64, 5511-5523.

24. Anné, S.; Yong, W.; Vandewalle, M. Synlett 1999, 1435-1437.

25. Sugita, Y.; Sakai, J.-i.; Sato, M.; Kaneko, C. J Chem Soc Perkin Trans 1 1992, 2855-2861.

26. Hoye, T. R.; Wang, J. J Am Chem Soc 2005, 127, 6950-6951.

27. Kaneda, K.; Uchiyama, T.; Fujiwara, Y.; Imanaka. T.; Teranishi, S. J Org Chem 1979, 44, 55-63.

28. Micalizio, G. C.; Roush, W. R. Org Lett 2001, 3, 1949-1952.

29. Smitrovich, J. H.; Woerpel, K. A. J Org Chem 1996, 61, 6044-6046.

30. Mitsunobu O. Synthesis 1981, 1-28.

Biographies of authors

Hideo Kigoshi was born in 1959 in Gifu Prefecture, Japan. After he received his M.S. degree from Nagoya University in 1983, he was appointed Assistant Professor at Nagoya University in 1984. He received his Ph.D. degree from Nagoya University in 1989. He served as a postdoctoral fellow with E. J. Corey (Harvard University) in 1990-1991. He became Associate Professor at Nagoya University in 1994. In 2000, he moved to the University of Tsukuba as Professor of Chemistry. His research interests lie in the field of chemistry and chemical biology of bioactive natural products. He was awarded the Chemical Society of Japan Award for Young Chemists in 1993.

Ichiro Hayakawa was born in 1972 in Kanagawa, Japan. He received his B.S. degree from Kanagawa University under the direction of Professor Yoshiaki Kamano in 1996 and his M.S. from Shizuoka University under the direction of Professor Daisuke Uemura in 1998. From 1998 to 2001, he worked at JSR Corporation as a research chemist. He received his Ph.D. from Nagoya University under the direction of Professor Daisuke Uemura in 2004. That same year, he was appointed Research Associate in Professor Hideo Kigoshi's group at the University of Tsukuba. His current research interests include total synthesis of bioactive natural products and development of synthetic strategies. 